Article

\title{
First Data on the Helminth Community of the Smallest Living Mammal on Earth, the Etruscan Pygmy Shrew, Suncus etruscus (Savi, 1822) (Eulipotyphla: Soricidae)
}

\author{
María Teresa Galán-Puchades ${ }^{1, * \mathbb{D}}$, Santiago Mas-Coma ${ }^{2}$, María Adela Valero ${ }^{2}$ a and Màrius V. Fuentes ${ }^{1}(\mathbb{D}$ \\ 1 Parasite and Health Research Group, Department of Pharmacy and Pharmaceutical Technology and \\ Parasitology, Faculty of Pharmacy, University of Valencia, 46100 Burjassot, Valencia, Spain; \\ mario.v.fuentes@uv.es \\ 2 Departamento de Parasitología, Facultad de Farmacia, Universidad de Valencia, \\ 46100 Burjassot, Valencia, Spain; s.mas.coma@uv.es (S.M.-C.); madela.valero@uv.es (M.A.V.) \\ * Correspondence: mteresa.galan@uv.es
}

check for

updates

Citation: Galán-Puchades, M.T.; Mas-Coma, S.; Valero, M.A.; Fuentes, M.V. First Data on the Helminth Community of the Smallest Living Mammal on Earth, the Etruscan Pygmy Shrew, Suncus etruscus (Savi, 1822) (Eulipotyphla: Soricidae). Animals 2021, 11, 2074. https:// doi.org/10.3390/ani11072074

Academic Editor: Stefania Perrucci

Received: 15 June 2021

Accepted: 9 July 2021

Published: 12 July 2021

Publisher's Note: MDPI stays neutral with regard to jurisdictional claims in published maps and institutional affiliations.

Copyright: (c) 2021 by the authors. Licensee MDPI, Basel, Switzerland. This article is an open access article distributed under the terms and conditions of the Creative Commons Attribution (CC BY) license (https:// creativecommons.org/licenses/by/ $4.0 /)$.
Simple Summary: The Etruscan shrew, Suncus etruscus, is the smallest living mammal on Earth. Its minute size (most adults weigh 1.8-3 g with a body length of 35-48 mm) makes it extremely difficult to catch in small mammal traps. The French scientist Dr Roger Fons (1946-2016) developed a particular trapping method which allowed him to assemble the largest collection of $S$. etruscus in the world. We had the unique opportunity of studying, for the first time, the helminth community of a total of 166 individuals of the Etruscan shrew. We found six cestode species, specifically, two extraintestinal larvae, and four intestinal adult tapeworms, as well as one adult nematode species in the stomach and several nematode larvae. Neither trematode nor acanthocephalan species were detected. Approximately $50 \%$ of the individuals harbored tapeworms presenting a two-host life cycle with arthropods as intermediate hosts, a fact that is consistent with its insectivorous diet. The adult helminth community found is highly specific of this shrew whose numerous physiological adaptations due to its small size have probably influenced its helminth spectrum as well as its helminth specificity.

Abstract: Suncus etruscus is the smallest living mammal on Earth by mass. Most adults weigh 1.8-3 g with a body length of 35-48 mm. Catching it in small mammal traps in nature is extremely difficult due to its minute size, and therefore special trapping methods must be used. We had the unique opportunity of studying, for the first time, the helminth parasites of 166 individuals of S. etruscus, part of the largest collection in the world, which belonged to the French scientist Dr Roger Fons (1942-2016). A total of 150 individuals were captured in the Banyuls-Cerbère area (France) and 16 in the island of Corsica (France). We found seven helminth species, specifically, the cestodes Joyeuxiella pasqualei larvae, Mesocestoides sp. larvae, Staphylocystis claudevaucheri, S. banyulsensis, S. cerberensis, and Pseudhymenolepis sp., and the nematodes Aonchotheca sp. and Nematoda gen. sp. larvae. Neither trematodes nor acanthocephalans were detected. We provide prevalences, infracommunity compositions, and helminth associations. The adult helminth community of S. etruscus seems to be highly specific, i.e., oioxenous, and linked to its insectivore diet. Due to its small size, S. etruscus has undergone numerous physiological adaptations that have probably influenced its helminth spectrum as well as its helminth specificity.

Keywords: Suncus etruscus; Mesocestoides sp. larvae; Joyeuxiella pasqualei larvae; Staphylocystis claudevaucheri; S. cerberensis; S. banyulsensis; Pseudhymenolepis sp.; Aonchotheca sp.; helminth community

\section{Introduction}

Suncus etruscus, the Etruscan shrew, also known as the Etruscan pygmy shrew, the Pygmy white-toothed shrew, or the Savi's pygmy shrew, is, by mass, the smallest living 
mammal on Earth. Most adults weigh 1.8-3 $\mathrm{g}$ with a body length of $35-48 \mathrm{~mm}$, being 20 times lighter than the average adult mouse [1] (Figure 1). This miniscule mammal species is widespread throughout Southern Europe, Northern Africa, and Central Asia. Suncus etruscus has indeed one of the largest distribution ranges among insectivore mammals encompassing the territory from the Iberian Peninsula to Kalimantan (Borneo) Island (Indonesia), where they occupy abandoned olive groves and vineyards with old dry stone walls and stone-piles as well as low maquis shrubs and Mediterranean oak and pine forests [2]. Recently, the Etruscan shrew has also been detected in Russia [3].

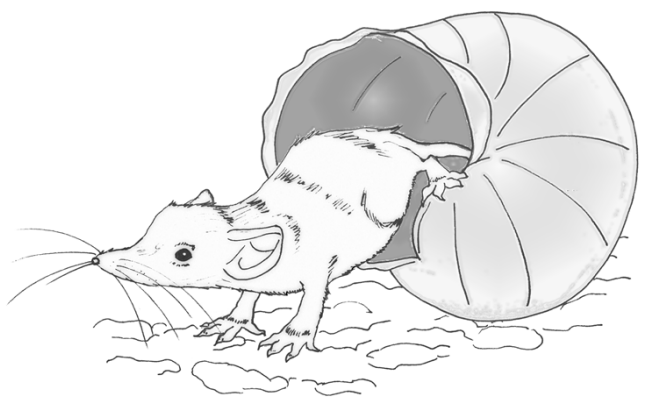

(a)

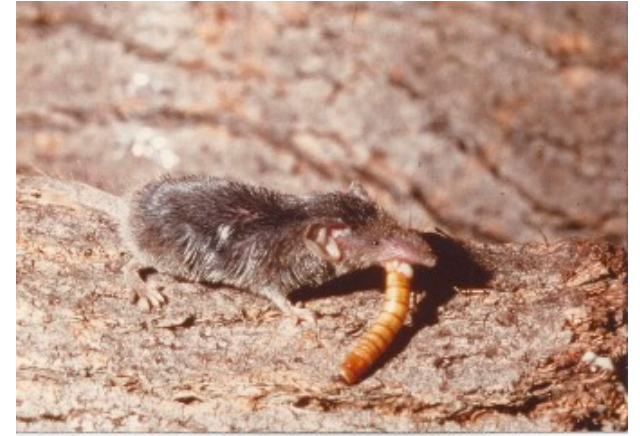

(b)

Figure 1. Suncus etruscus: (a) Comparative size of the smallest living mammal on Earth (illustration by Angela Debenedetti, PhD); (b) An individual of the Etruscan shrew ingesting a yellow mealworm (Tenebrio molitor) larva (R. Fons photo collection).

Despite its large geographical distribution, only a small number of individuals of this species have been caught in the world, since catching S. etruscus in small mammal traps in nature is extremely difficult due to its minute size, and therefore special trapping methods must be used. In fact, its existence was only known thanks to the findings of its predator (the barn owl Tyto alba) pellets [4].

Roger Fons (1942-2016), Directeur de Recherche at the French CNRS (Centre National de la Recherche Scientifique), was the only specialist of the Etruscan pygmy shrew in the world, carrying out his scientific activity at Laboratoire Arago (University Pierre et Marie Curie, Paris VI, Banyuls-sur Mer, France). He published numerous scientific articles dealing with $S$. etruscus, as for instance those concerning trapping and breeding methods [4,5], morphology [6-11], evolution and systematics [12], biology/ecology [5,6,13-17], ethology [14,18-20], and physiology [14,21-30], among others.

Due to our, not only scientific collaboration, but also friendship with Dr Fons, we had the unique opportunity of studying, for the first time, the helminth parasites of S. etruscus, since he owned the largest collection of this shrew in the world. In fact, in the 1980s we jointly published the finding of three new intestinal cestodes, namely the hymenolepidids Hymenolepis claudevaucheri [31], H. cerberensis [32], and H. banyulsensis [33].

In addition to the three new tapeworm species, we found some other helminths in the studied individuals. Herein, we present the first data on the global helminth community of the Etruscan shrew, and we would like this article to be a tribute to Dr Fons, who owed his outstanding and well-deserved career to his hard work, his ability to solve technical problems, and the passion that drove him on.

\section{Materials and Methods}

\subsection{Study Areas and Hosts}

A total of 166 S. etruscus ( 97 males and 69 females) was examined in order to study their helminth parasites. Concerning the study areas, 150 individuals (86 males and 64 females) were trapped in the rural areas of the municipalities of Banyuls-sur-Mer and Cerbère (Pyrénées-Orientales department, France) and 16 individuals (11 males and five females) were captured in the Island of Corsica (France). Considering the small size of S. etruscus, 
conventional traps do not work. Dr Fons, therefore, designed, what he called "interception traps" (pitfall traps), consisting in metal boxes $(25 \mathrm{~cm}$ high, $15 \mathrm{~cm}$ wide) perforated at the bottom (to prevent the accumulation of water) and buried in the ground-to-ground level. The traps were placed mainly in three types of biotopes, i.e., at the bottom of dry stone walls (not cemented) of abandoned vineyards, olive terraces reclaimed by xerophilic vegetation, and those placed in maquis shrubs. Traps do not contain any kind of bait to prevent ants from destroying the preys (Figure 2).

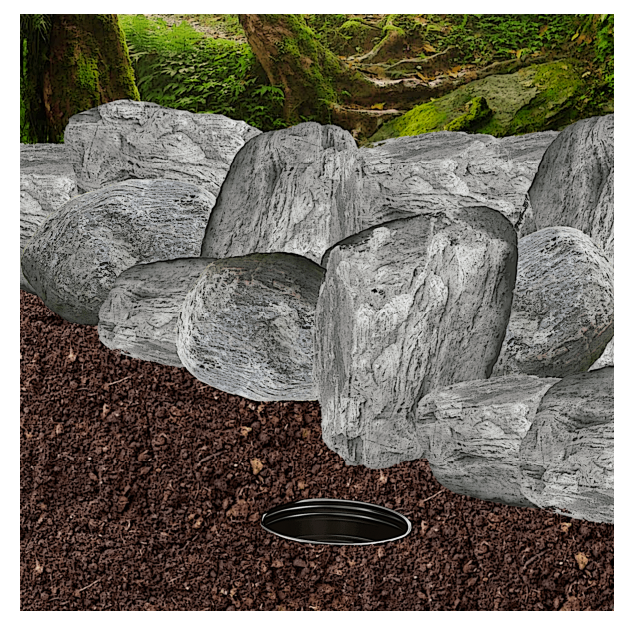

Figure 2. Interception trap buried to ground level at the bottom of a dry stone wall (illustration by Angela Debenedetti, PhD).

Not only can S. etruscus be captured by means of these traps but also other Soricidae like Crocidura russula or C. suaveolens. Likewise, the invertebrate fauna of the area, susceptible to being part of the diet of these insectivores, can also be caught up.

Interception traps were checked up on a daily basis, and live Etruscan shrews were kept in captivity by Dr Fons. Most of the animals found dead in the traps were preserved in $85 \%$ ethanol. We also had the opportunity of studying some individuals of S. etruscus shortly after their death in the interception traps placed in the Banyuls/Cerbère area along our long-lasting collaboration with Dr Fons.

The animal weight could be determined only in the 31 specimens that were not preserved in ethanol. This weight varied between $1.3-2.7 \mathrm{~g}(1.8 \mathrm{~g})$.

No ethical approval was required at the time Dr Fons conducted his surveys, i.e., in the nineteen sixties-eighties.

\subsection{Parasitological Techniques}

Suncus etruscus individuals were dissected in order to extract the internal organs at Laboratoire Arago. Due to the small size of S. etruscus, the specimens were dissected under a stereomicroscope (Meiji Techno ${ }^{\circledR}$ EMT Stereo Microscope). The organs (gastrointestinal tract, lungs, liver, spleen, urinary system) were place in saline in Petri dishes and were stereomicroscopically examined. The helminths found (cestodes and nematodes) were placed in $70 \%$ ethanol until their subsequent study at Department of Parasitology of University of Valencia.

Following conventional helminthological techniques, cestodes were stained with alcoholic hydrochloric carmine for $24 \mathrm{~h}$. Subsequently, the helminths were partially destained with acidified alcohol, dehydrated in an alcohol series, cleared with xylene, and mounted in Canada balsam between slide and cover slip. Prior to the staining process, in the case of adult cestode stages, the last gravid proglottids were separated in order to carry out the morphological study of the tapeworm eggs, since the staining and dehydration procedures tend to alter the egg morphology. These last gravid proglottids were placed on a slide in a drop of lactophenol, a clearing fluid, and were subsequently broken in order to liberate 
the eggs. Those tapeworms that were collected alive were previously relaxed and fixed by shaking them in hot $70 \%$ ethanol.

Nematodes were studied by direct examination between slide and cover slip with lactophenol.

\subsection{Statistical Analysis}

The number of parasitized shrews, the overall prevalence of infection, as well as the prevalence of each helminth species, were analyzed. Standard non-parametric tests were applied to analyze the influence of host sex, season, and type of biotope (abandoned vineyards, olive terraces, and maquis shrubs) on the prevalence of the helminth parasites by Binary Logistic Regression (BRL). Positive or negative helminth associations were calculated by means of a chi-squared test $\left(\chi^{2}\right)$. Statistical significance was established at $p<0.05$. The IBM SPSS Statistics 26 for Windows software package was used for statistical analysis.

\section{Results}

Eighty-four out of the 166 S. etruscus examined (50.60\%) were parasitized. Table 1 details the helminth community found, made up of seven helminth species, including the extra-intestinal larval stages (metacestodes) of two cestodes, Mesocestoides sp. Vaillant, 1863 larvae and Joyeuxiella pasqualei (Diamare, 1983) larvae (Figure 3), the intestinal adult stages of four more tapeworms, Staphylocystis claudevaucheri (Mas-Coma, Fons, GalánPuchades, and Valero, 1984), S. cerberensis (Mas-Coma, Fons, Galán-Puchades, and Valero, 1986), S. banyulsensis (Mas-Coma, Fons, Galán-Puchades, and Valero, 1986) and Pseudhymenolepis Joyeux and Baer, 1935 sp. (Figures 4-6), and one stomachal nematode species, Aonchotheca López-Neyra, 1947 sp. In addition to these helminths, fragments of tapeworm strobilae consistent with cestodes belonging to the hymenolepididae family were detected in nine S. etruscus. However, due to their bad preservation, it was impossible to classify them at genus or species level. Likewise, in six individuals, young larval stages of nematodes found in the stomach or abdominal cavity were classified as Nematoda gen. sp. larvae due to the lack of distinctive morphological features.

Table 1. Helminth community of the 166 Suncus etruscus studied.

\begin{tabular}{ccccc}
\hline Helminth Species & Microhabitat & $\mathbf{n}$ & $\boldsymbol{p ~ ( \% )}$ & $\mathbf{9 5 \%} \mathbf{C I}$ \\
\hline Mesocestoides sp. larvae & abdominal cavity & 1 & 0.60 & $0.10-3.96$ \\
Joyeuxiella pasqualei larvae & liver & 2 & 1.20 & $0.10-3.96$ \\
Staphylocystis claudevaucheri & intestine & 31 & 18.67 & $13.42-25.72$ \\
Staphylocystis cerberensis & intestine & 5 & 3.01 & $1.01-6.85$ \\
Staphylocystis banyulsensis & intestine & 14 & 8.43 & $4.46-13.13$ \\
Hymenolepididae gen. sp. indet. & intestine & 9 & 5.42 & $2.27-9.47$ \\
Pseudhymenolepis sp. & intestine & 47 & 28.31 & $21.42-35.39$ \\
\hline Overall cestodes & & 80 & 48.19 & $40.30-55.78$ \\
\hline Aonchotheca sp. & stomach & 2 & 1.20 & $0.10-3.96$ \\
Nematoda gen. sp. larvae & stomach/ & 6 & 3.61 & $1.61-8.18$ \\
\hline Overall nematodes & abdominal cavity & & & \\
\hline Overall parasitism prevalence & & 8 & 4.82 & $2.27-9.47$ \\
\hline
\end{tabular}

Abbreviations: $n$, number of parasitized S. etruscus; $p$, prevalence; CI, confidence interval. 


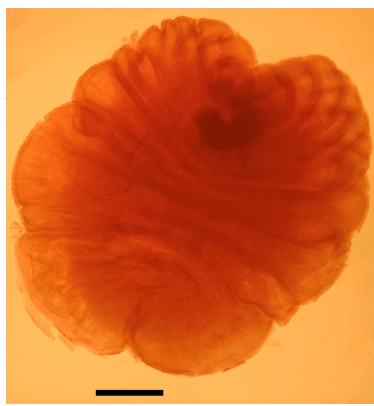

(a)

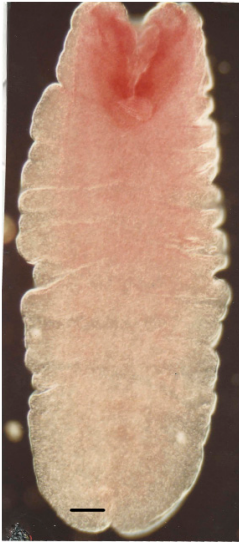

(b)

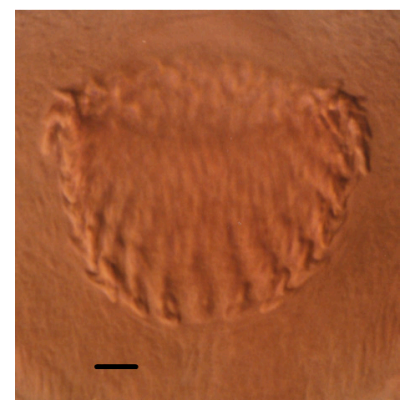

(c)

Figure 3. Extraintestinal metacestodes of S. etruscus: (a) tetrathyridium of Mesocestoides sp.; (b) cysticercoid of Joyeuxiella pasqualei; (c) detail of the rows of hooks of the J. pasqualei metacestode. Scale bars: (a), $400 \mu \mathrm{m}$; (b), $150 \mu \mathrm{m}$; (c), $20 \mu \mathrm{m}$.

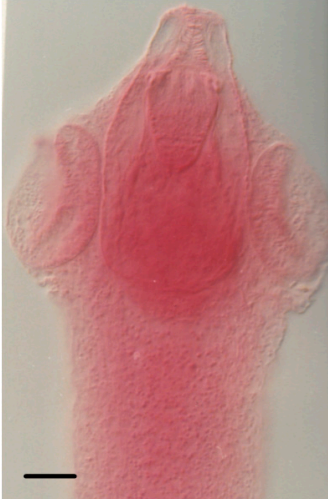

(a)

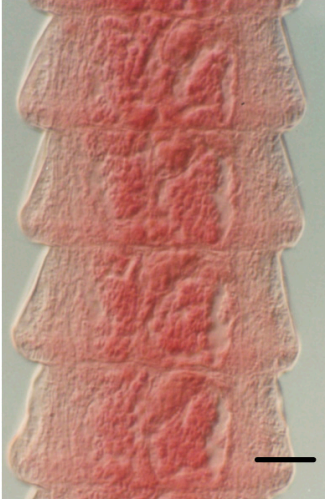

(b)

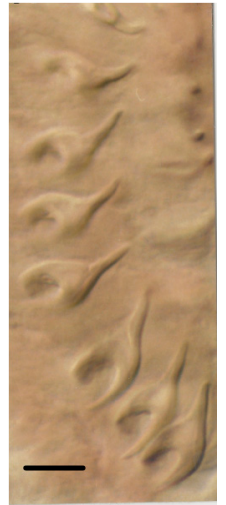

(c)

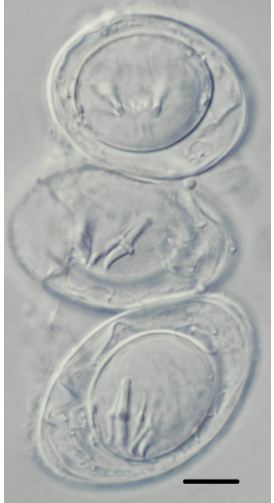

(d)

Figure 4. S. claudevaucheri: (a) armed scolex; (b) postmature proglottids. S. cerberensis: (c) rostellar hooks; (d) eggs. Scale bars: (a), $30 \mu \mathrm{m} ;(\mathbf{b}), 80 \mu \mathrm{m}$; (c,d), $10 \mu \mathrm{m}$.

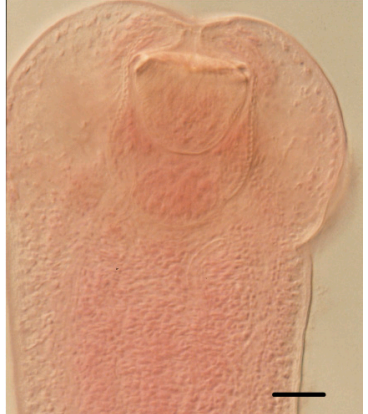

(a)

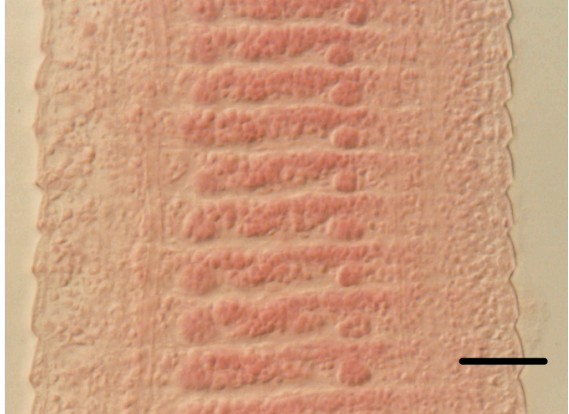

(b)

Figure 5. S. banyulsensis: (a) armed scolex; (b) premature proglottids. Scale bars: (a,b), $30 \mu \mathrm{m}$. 


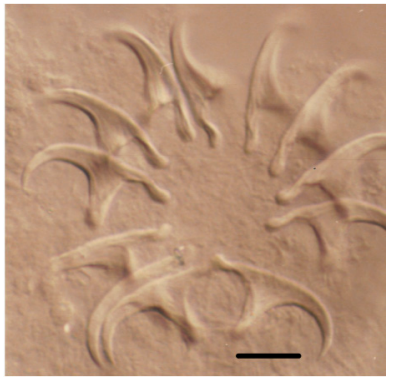

(a)

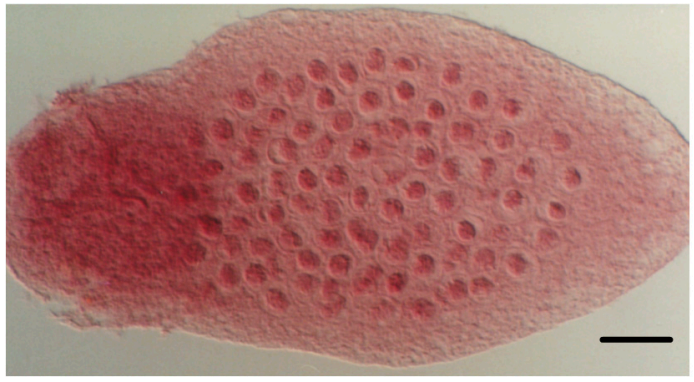

(b)

Figure 6. Pseudhymenolepis sp.: (a) rostellar hooks; (b) gravid proglottids containing uniovular capsules. Scale bars: $(\mathbf{a}, \mathbf{b}), 10 \mu \mathrm{m}$.

Half of the S. etruscus population (50.60\%) was parasitized. Cestodes, with almost 50\% of parasitation, were clearly the most prevalent parasites in the helminth community, whilst nematodes were scarcely distributed in the host population. Only 5 individuals (3.01\%) harbored not only cestodes but also nematodes. Neither trematodes nor acanthocephalans were detected.

Pseudhymenolepis sp. (28.31\%) was the most prevalent cestode followed by S. claudevaucheri (18.67\%).

According to sex, 52 out of the 97 males were parasitized (53.61\%) and 32 out of the 69 females $(46.38 \%)$. There were no statistical differences when considering host sex, season, or biotope of capture.

Concerning infracommunities (helminths of different species in the same host- [34]), 58 S. etruscus harbored only one helminth species (64.29\% among the parasitized), 20 harbored two species (23.81\%), five harbored three species (5.95\%), and one S. etruscus (1.19\%) captured in the Banyuls/Cerbère area was parasitized by the four intestinal adult tapeworm species.

Table 2 summarizes the helminth communities of the Etruscan shrew according to the studied area, i.e., Banyuls/Cerbère and Corsica.

Table 2. Helminth community of Suncus etruscus according to the studied areas.

\begin{tabular}{|c|c|c|c|c|}
\hline Helminth Species & $\begin{array}{c}\mathrm{B} / \mathrm{C}(\mathrm{N}=150) \\
\mathrm{n} / p(\%)\end{array}$ & $95 \% \mathrm{CI}$ & $\begin{array}{c}\text { Corsica }(\mathrm{N}=16) \\
\mathrm{n} / p(\%)\end{array}$ & $95 \%$ CI \\
\hline Mesocestoides sp. larvae & - & - & $1 / 6.25$ & $0.16-30.00$ \\
\hline Joyeuxiella pasqualei larvae & $2 / 1.33$ & $0.01-4.20$ & - & - \\
\hline Staphylocystis claudevaucheri & $29 / 19.33$ & $13.17-26.10$ & $2 / 12.50$ & $1.56-37.96$ \\
\hline Staphylocystis cerberensis & $3 / 2.00$ & $0.45-5.71$ & $2 / 12.50$ & $1.56-37.96$ \\
\hline Staphylocystis banyulsensis & $14 / 8.43$ & $4.30-13.46$ & - & - \\
\hline Hymenolepididae gen. sp. indet. & $7 / 4.67$ & $2.17-9.76$ & - & - \\
\hline Pseudhymenolepis sp. & $43 / 28.67$ & $22.00-36.85$ & $4 / 25.00$ & $7.31-51.69$ \\
\hline Aonchotheca sp. & $2 / 1.33$ & $0.01-4.20$ & - & - \\
\hline Nematoda gen. sp. larvae & $6 / 4.00$ & $1.53-8.46$ & - & - \\
\hline Overall prevalence & $78 / 52.00$ & $44.00-60.00$ & $6 / 37.50$ & $15.31-63.51$ \\
\hline
\end{tabular}

Abbreviations: B/C, Banyuls/Cerbère; N, number of S. etruscus studied; n, number of parasitized S. etruscus; $p$, prevalence; $\mathrm{CI}$, confidence interval.

The statistical comparison between the studied areas revealed no differences in the overall prevalence of helminths, although the low number of S. etruscus studied in Corsica limits the statistical analysis. This very much smaller number of S. etruscus studied in Corsica compared to those examined in Banyuls/Cerbère (16 vs. 150), understandably limits any comparative analysis between these two areas. Therefore, the poorer helminth community of S. etruscus in the island (lack of certain cestodes or no nematodes) is probably due to this fact. In spite of these different numbers, Pseudhymenolepis sp. is the most prevalent helminth in both areas. 
Three positive helminth associations, i.e., S. claudevaucheri-S. banyulsensis $\left(\chi^{2}=7755\right.$; $p=0.0054)$, S. claudevaucheri-S. cerberensis $\left(\chi^{2}=15.297 ; p<0.0001\right)$, and S. banyulsensis-S. cerberensis $\left(\chi^{2}=11.534 ; p=0.0007\right)$ were found.

\section{Discussion}

\subsection{Helminth Populations}

\subsubsection{Tapeworm Metacestodes}

According to our results, S. etruscus represents a new host for the metacestodes of Mesocestoides sp. and Joyeuxiella pasqualei. In contrast with the remaining Cyclophyllidean cestodes, the life cycles of both tapeworms are not completely understood yet. Small mammals could act as (second?) intermediate hosts or paratenic hosts in the two life cycles [35].

- Mesocestoides sp.

Adult stages of tapeworms of the genus Mesocestoides infect a variety of terrestrial mammalian carnivores. In its life cycle, there seems to be a missing link in between the definitive hosts and the hosts harboring the metacestode, known as tetrathyridium (Figure 7). The host specificity of tetrathyridia is remarkably low, having been found in a large variety of animals such as mammals, birds, reptiles, and amphibians [36]. The repeated failures in trying to infect vertebrates with Mesocestoides eggs led to the assumption that there might be an invertebrate first intermediate host in this life cycle [37]. Various authors have proposed terrestrial arthropods such as dung beetles, ants, roaches, and mites as potential first intermediate hosts [38]. However, recently, it has been suggested that Mesocestoides might develop through a simple two-host (diheteroxenous) life cycle rather than an obligate three-host cycle (triheteroxenous), only using vertebrates as the intermediate host [39].

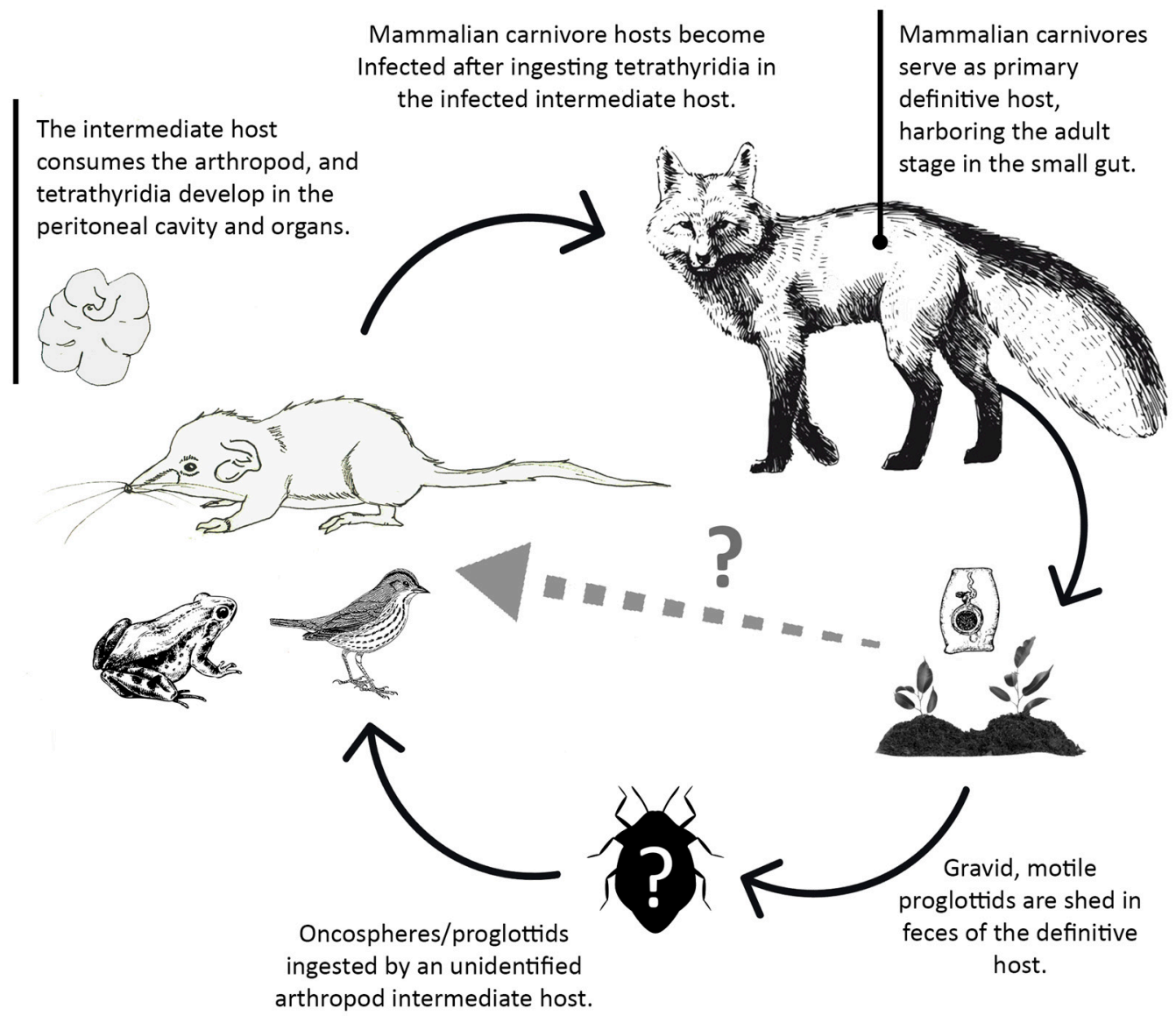

Figure 7. Partially known Mesocestoides life cycle (illustration by Angela Debenedetti, PhD). 
Five Mesocestoides tetrathyridia were found in the abdominal cavity of one individual of S. etruscus in the island of Corsica. No parasitized Etruscan shrew with this metacestode was found in the Banyuls/Cerbère area. Likewise, neither was tetrathyridia found in 69 Crocidura russula (the greater white-toothed shrew) studied in the same area [40]. However, 23 out of 141 (16.30\%) Crocidura suaveolens (the Lesser white-toothed shrew) from Corsica harbored tetrathyridia of Mesocestoides sp. [36]. Mass-infections were frequently detected in the positive shrews [40] (Figure 8). These cases in which up to hundreds of metacestodes were found in several C. suaveolens in Corsica could be a consequence of the asexual reproduction by tetrathyridia [41,42] or, assuming a two-host life cycle, a consequence of the lesser shrew having ingested the intact proglottids containing the parauterine organ which protects the high number of oncospheres included inside. Therefore, both of these reproductive strategies of Mesocestoides are probably lethal or very harmful for $S$. etruscus considering its minuscule size (tetrathyridia of up to $4.01 \mathrm{~mm}$ long $\times 3.85 \mathrm{~mm}$ wide were found in the infected S. etruscus from Corsica) (Figure 3a). As a consequence, parasitized Etruscan shrews would probably die or would be very easily preyed upon by the definitive host, which could explain why only one of 166 S. etruscus was found parasitized by Mesocesoides tetrathyridia. However, the absence of Mesocestoides tetrathyridia in the Etruscan shrew could also be a consequence, assuming a three-host life cycle, of the $S$. etruscus diet, which would normally not include the arthropod intermediate host.

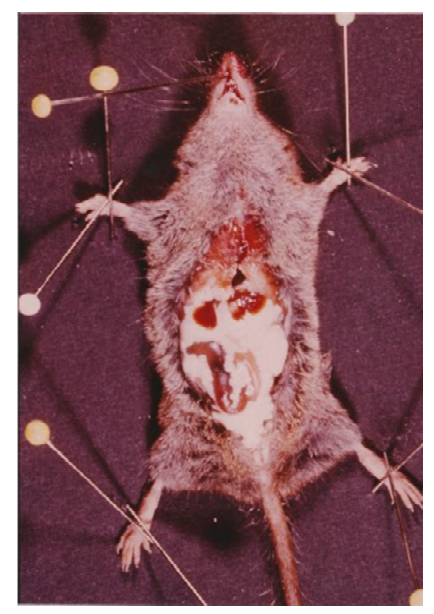

Figure 8. Mass-infection by Mesocestoides tetrathyridia in an individual of Crocidura suaveolens captured in the island of Corsica (France).

In the Mesocestoides life cycle, S. etruscus is probably an intermediate host instead of a paratenic one. The Etruscan shrew could become infected through the ingestion of either an infected arthropod (in the case of a three-host life cycle), or through the ingestion of gravid proglottids (in the case of a two-host life cycle). Although S. etruscus often kill insects of up to half their size, despite their hunger, they are frightened by and never attack vertebrates such as mice, birds, large reptiles, or amphibians that could harbor the tetrathyridia metacestodes [18]. However, when faced with a lack of nourishment, $S$. etruscus, just like other Soricidae, turns cannibal [18]. Therefore, S. etruscus could also act as paratenic host just in case the Etruscan shrew devoured an infected individual of its same species.

\section{- Joyeuxiella pasqualei}

The definitive hosts of the intestinal adult stages of J. pasqualei are mainly domestic cats, but the tapeworm has also been found to infect dogs, wolves, and servals [43]. Small reptiles, mainly lizards (Tarentola mauritanica, the common wall gecko, Hemidactylus frenatus, the house gecko and other similar reptiles) act as intermediate hosts which contain the cysticercoid metacestode that is found in the peritoneal cavity and liver (Figure 9). Sporadically, the cysticercoid has also been found in small mammals like the field mouse, 
Apodemus sylvaticus [44] and in the shrews Crocidura russula [44] and C. suaveolens [45]. Concerning its life cycle, due to the failure in infecting wall geckos with segments carrying the eggs, the existence of an insect first intermediate host was suggested [46]. However, laboratory experiments trying to infect insects like mealworms, cockroaches, and crickets with J. pasqualei eggs have failed so far [45].

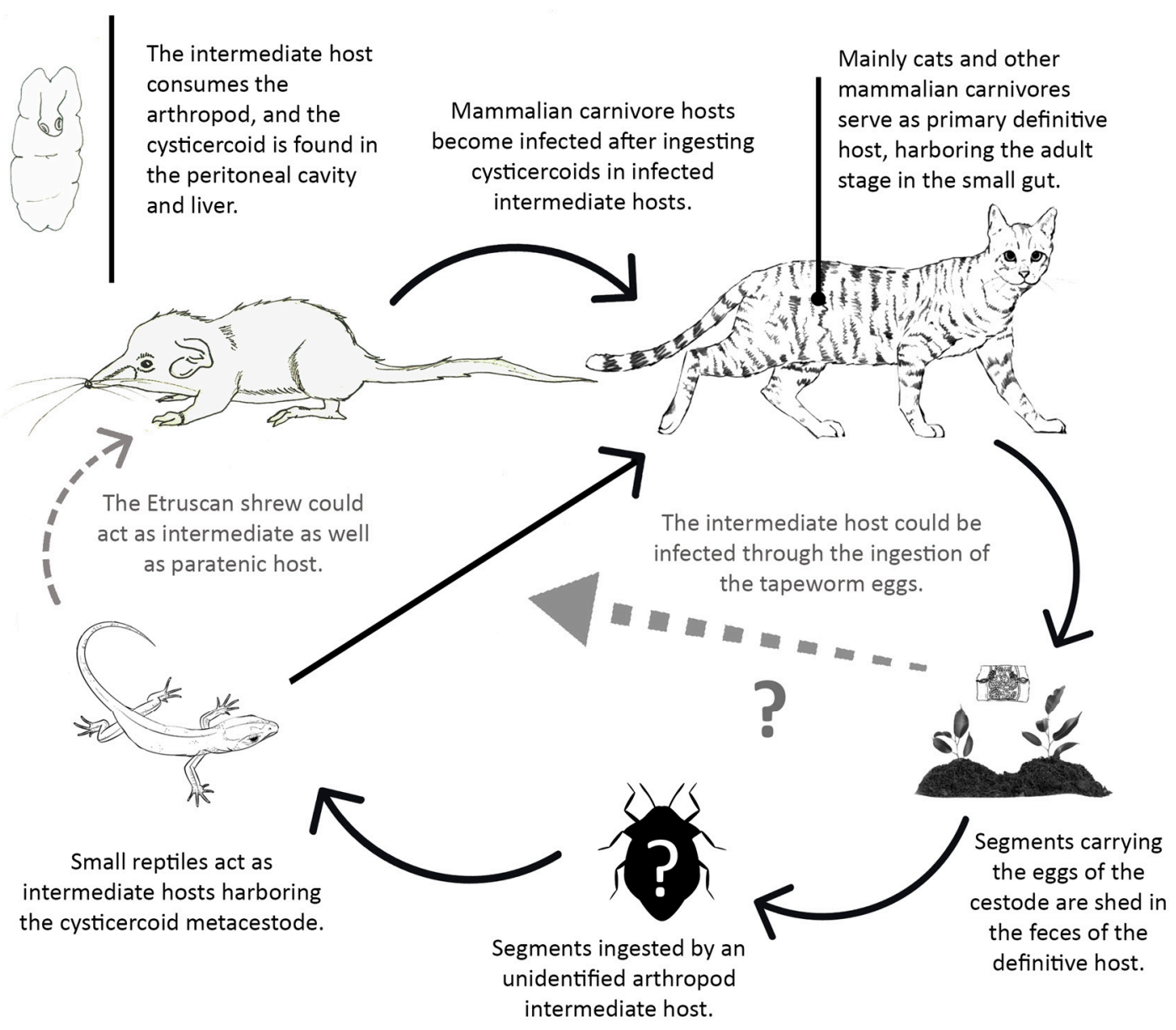

Figure 9. Partially known Joyeuxiella pasqualei life cycle (illustration by Angela Debenedetti, PhD).

In the liver of two individuals of S. etruscus captured in the Banyuls/Cerbère area, we found three small metacestodes of around $0.9-1.5 \mathrm{~mm}$ long and $0.4-0.7 \mathrm{~mm}$ wide (Figure 3b). No cysticercoid of this tapeworm was found in the 69 C. russula studied in the same area [40].

In the J. pasqualei life cycle, S. etruscus probably plays the role of second intermediate host (in the case of a three-host life cycle), becoming infected through the ingestion of a hypothetical insect first intermediate host. Assuming a two-host life cycle, S. etruscus would act as intermediate host becoming infected through the ingestion of the tapeworm eggs. Due to its minuscule size, becoming infected by means of the depredation of a gecko-the prey being larger than the predator-seems unlikely. However, Dr Fons observed that, in captivity, S. etruscus sometimes attacks the common wall gecko [18]. Therefore, the Etruscan shrew could act as intermediate as well as paratenic host in the life cycle of $J$. pasqualei.

Just as in the case of the Mesocesoides life cycle, S. etruscus could also act as paratenic host of $J$. pasqualei by means of cannibalism.

\subsubsection{Tapeworm Adult Stages}

\section{- Staphylocystis Species}


The three intestinal adult tapeworms found in S. etruscus, namely Hymenolepis claudevaucheri, $H$. cerberensis, and $H$. banyulsensis, were described as new cestode species in the 1980s [31-33]. Posteriorly, and according to the key to identify to generic level cestodes of the family Hymenolepididae, published in 1994 [47], the species were reallocated to the genus Staphylocystis, since the three species present an armed rostellum. According to the aforementioned key, Hymenolepis includes species with unarmed rostella.

These intestinal hymenolepidids clearly show morphological similarities with those of the genus Crocidura, i.e., they all have a scolex with a well-developed rostellum inside a well-marked sheath and armed with a typical row of hooks. In addition, no representative of tapeworms belonging to the family Arostrilepididae (hymenolepidids with unarmed scolex and without rostellum, present in shrew of the subfamily Soricinae [48]) has been found in S. etruscus.

As far as we know, these three Staphylocystis species have not been found in any other small mammal in the world so far, thus indicating that they are specific of S. etruscus. In fact, we analyzed 662 Crocidura russula and 171 C. suaveolens from the same geographical areas in which these two shrews coexist with S. etruscus in southern Europe (both, in different islands and on the mainland) without finding them [40].

Just as for the rest of cestodes of the Hymenolepididae family, a two-host life cycle with terrestrial arthropods acting as intermediate hosts harboring the cysticercoid is assumed for these tapeworms, for which the Etruscan shrew acts as definitive host (Figure 10). The positive associations found among some of these tapeworms suggest either that some of the species could share a common intermediate host, or that different arthropods intermediate hosts are commonly included in the S. etruscus diet.

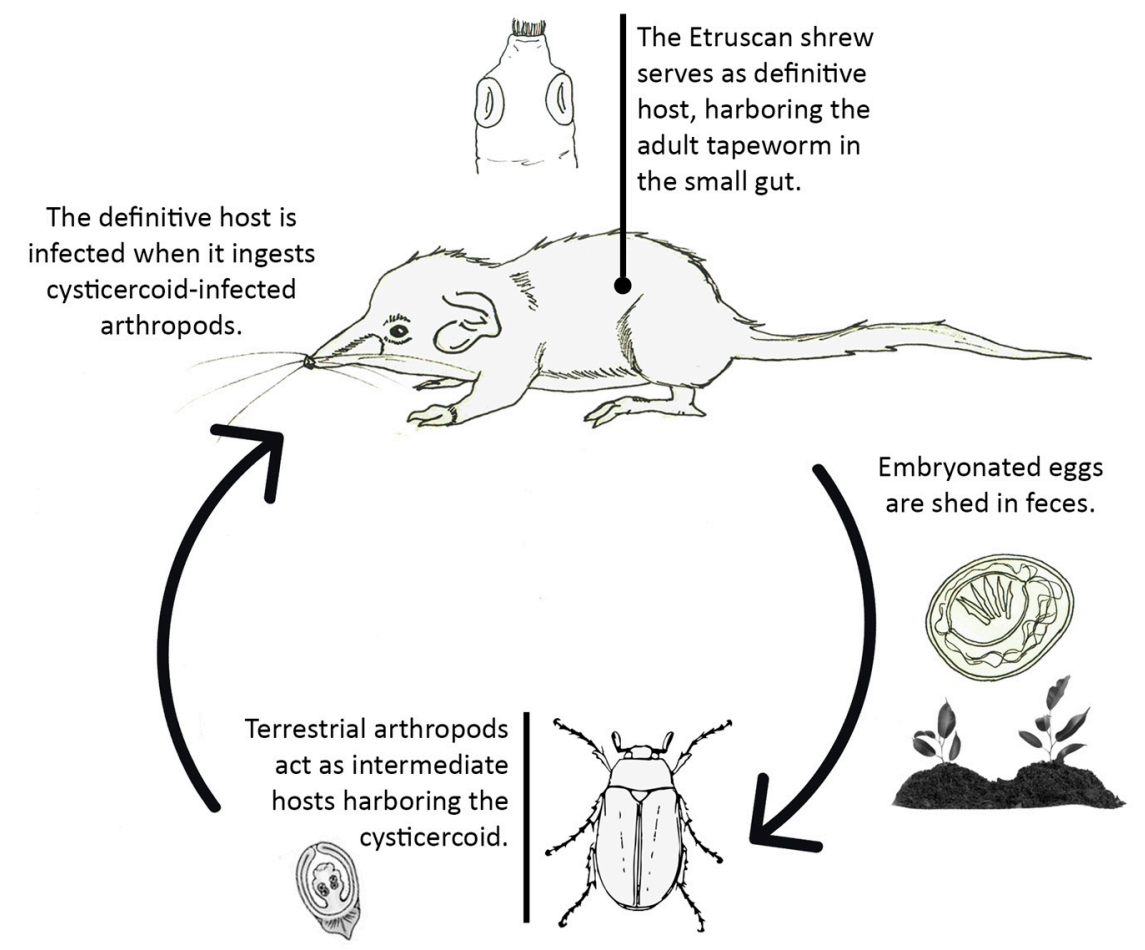

Figure 10. Probable life cycle of the cestode species of the family Hymenolepididae infecting $S$. etruscus (illustration by Angela Debenedetti, PhD).

- Pseudhymenolepis sp.

Almost $56 \%$ of the parasitized S. etruscus harbored this tapeworm, thus becoming the most prevalent parasite of its helminth community.

The peculiar cestodes of this genus have a hyperapolitic strobila (proglottids detach from the posterior part of the strobila when they are immature and live separately in the 
intestine) and the uterus breaks down into uniovular capsules. This genus parasitizes exclusively white-toothed shrews (subfamily Crocidurinae), specifically of the genera Crocidura, Diplomesodon, and Suncus.

Currently, Pseudhymenolepis species of the genus Crocidura include: P. redonica Joyeux and Baer, 1935 (C. russula, Europe), P. eburnea Hunkeler, 1970 (C. jouvenetae, Africa), P. papillosa Hunkeler, 1970 (C. flavescens, C. jouvenetae, C. poensis, Africa), P. graeca Vaucher, 1984 (C. suaveolens, Greece), P. nepalensis Sawada and Koyasu, 1991 (C. suaveolens, Kazakhstan), P. japonica Sawada and Harada, 1991 (C. dsinezumi, Japan), P. crociduri Velikanov, 1997 (C. suaveolens, Turkmenistan), and P. spasskii Velikanov, 1997 (C. suaveolens, Turkmenistan) [49-54].

Pseudhymenolepis turkestanica Tkach and Velikanov, 1991 (Middle Asia) is specific of the only living representative of the genus Diplomesodon, the piebald shrew D. pulchellum [55].

Regarding Pseudhymenolepis of the genus Suncus, those reported in S. murinus in different Asian countries are: P. solitaria (Meggit, 1927); P. eisenbergi Cruz and Sanmugasunderam, 1971; P. guptai Gupta and Singh, 1988; P. lucknowensis Gupta and Savita, 1989; and P. nepalensis Sawada and Koyasu, 1991 [51,56,57]. Pseudhymenolepis suncusi Gupta and Sinha, 1984, and P. guptai were also reported in S. striatus in Asian countries [58,59].

P. eisenbergi as well as P. suncusi and P. guptai are not hyperapolitic cestodes. Therefore, according to the aforementioned key to classify cestodes [47], these species do not belong to the Pseudhymenolepis genus. P. lucknowensis (India) is named in a paper by Sawada and Ohono [56], however, we have not found its original description in the literature to find out whether it is, or not, a hyperapolitic tapeworm.

In accordance with this distribution among Crocidurinae shrews, the species belonging to the Pseudhymenolepis genus show a high degree of specificity at host genus level. There is only one exception, the presence of P. nepalensis, a parasite of S. murinus in C. suaveolens. The finding was published in a congress abstract [60], however, it was not endorsed by any subsequent scientific article, so there may be a reasonable doubt about its specific identification.

The morphological characteristics of the Pseudhymenolepis species found in S. etruscus in both study areas, substantially differ from those of the currently known Pseudhymenolepis species. The number, size, and hook morphology (Figure 6a), as well as the size and morphology of the gravid proglottids (number of uniovular uterine capsules) (Figure 6b) allow the morphological distinction of this species. Therefore, based only on morphology, a new species could be proposed. However, we also found in four out of $13(30.76 \%)$ individuals of $C$. suaveolens from the island of Porquerolles (Iles d'Hyères, France, in which the lesser white-toothed shrew coexists with S. etruscus), several proglottids and scolices of a species of Pseudhymenolepis similar to those found in S. etruscus [40]. Consequently, pending molecular studies of nuclear ribosomal RNA (complete ITS region and partial $28 \mathrm{~S}$ region) are needed to support the status of the Pseudhymenolepis found, both in S. etruscus and C. suaveolens.

Regarding the Pseudhymenolepis life cycle, its cysticercoids have been found in the flea Ctenophtalmus arvernus [61] and in the arachnid Phalangium opilio, the most widespread species of harvestman (opiliones) in the world [62]. No fleas have ever been found in the Etruscan pygmy shrew, probably due to its distinctly short and fine fur [63]. Therefore, other arthropods than fleas would have to act as intermediate hosts of the species of Pseudhymenolepis parasitizing, at least, S. etruscus (Figure 10). Considering that this tapeworm is the most prevalent parasite of the S. etruscus helminth community, the arthropod intermediate host must be a staple, more than a sporadic one, in its diet.

\subsubsection{Nematodes}

Herein, we report the first findings of nematode larvae and the adult stages of Aonchotheca sp. in S. etruscus.

Two adult nematode specimens, a male and a female, were found in the stomach of two Etruscan shrews trapped in the Banyuls/Cerbère area (prevalence 1.33\%, Table 2). 
Based on their morphological characteristics, both, male and female, were classified as belonging to the genus Aonchotheca Lopez-Neyra, 1947 sensu Moravec (1982) [64]. This genus includes capillariid species with male worms having lateral alae, a caudal bursa, a spicule, and a non-spiny cirrus.

Aonchotheca minuta (Chen, 1837) Moravec 1982, is the only species of the genus reported in a white toothed-shrew of the genus Suncus, in particular, in S. murinus in Asian countries. In different species of the genus Crocidura, the following have been reported: $A$. africana (Khalil, 1977) Mas-Coma and Galán-Puchades, 1985 (C. fumosa schistacea, Tanzania), A. helvetica Mas-Coma and Galán-Puchades, 1985 (C. russula, Switzerland), A. europea MasComa and Galán-Puchades, 1985 (C. russula, southern Europe), Aonchotheca sp. I Mas-Coma and Galán-Puchades, 1985 (C. russula, Belgium), Aonchotheca sp. II Mas-Coma and GalánPuchades, 1985 (C. leucodon, Bulgaria), and A. crociduri Asakawa, Kamiya, and Ohbayashi, 1988 (C. dsinezumi dsinezumi, Japan) [65,66].

Although the genus Aonchotheca has host specificity [65], the same species have sporadically been reported in other mammalian families [67]. In the case of the Aonchotheca specimens of $S$. etruscus, due to the scarcity of the material obtained, specific identification was not possible. Therefore, we were not able to find out if this species of Anchotheca is specific of the Etruscan shrew and, consequently, it would be a new species, or if S. etruscus and C. russula share the species A. europaea, which was found in the greater white-toothed shrew trapped in the same study area (unpublished data).

The life cycle of the members of the genus Aonchotheca is known for just a few species; they are diheteroxenous, with an invertebrate as intermediate host harboring the infective third-stage larvae which is acquired by the definitive host, S. etruscus in this case, through the ingestion of the intermediate host [68].

\subsection{Helminth Community}

According to our results, the helminth community of the 166 individuals of S. etruscus examined is exclusively made up of cestodes and nematodes. The species richness found, without considering the undetermined nematode larvae, consists of 7 helminth parasites. Trematodes and acantocephalans were absent and, although present, the nematode spectrum was remarkably poor.

Concerning the lack of trematode species in S. etruscus, we found different flukes in other shrews trapped in the same study areas, Banyuls/Cerbère and Corsica. Specifically, in 22 out of 69 C. russula analyzed in Banyuls/Cerbère, 31.88\% harbored intestinal trematodes belonging to Brachylaima (30.43\%) and Pseudoleucochloridium (2.89\%) genus, and $5.26 \%$ of the 95 C. suaveolens from Corsica harbored also Brachylaima sp. [40]. These terrestrial species have three-host life cycles with snails as first and second intermediate hosts. Although shedding light on the nutritional habits of S. etruscus in nature is difficult, Dr Fons supplied various mollusks, such as snails (Rumina decollata, Helicella sp., Helix sp.) and slugs (Testacella sp.) to the S. etruscus he kept in captivity, observing that the shrews tend to bite the mollusks which release mucus. The Etruscan shrews were satisfied by just licking the mucus; further attack on the snails being unusual [18]. Therefore, apparently, snails are not normally ingested by S. etruscus, thus making the presence of these trematodes in its helminth community rather unlikely.

Regarding the absence of acanthocephalans, we have to consider that the number of acanthocephalan species in small mammals is very low when compared to other helminths [69]. In fact, in 1026 shrews (662 C. russula, 171 C. suaveolens, 26 Crocidura sp., and 166 S. etruscus) studied in different locations of Spain and France, we only found a larval stage of Centrorhynchus appendiculatus in one individual of C. russula from the island of Ibiza $[40,44]$. Therefore, the lack of representatives of acanthocephalans in S. etruscus is not an unexpected phenomenon.

Shrews act as paratenic host in the two-host life cycle of acanthocephalans. The mammalian definitive host sheds the eggs that are ingested by different insects in terrestrial life cycles. In the intermediate host, the parasite goes through several developmental larval 
stages until it reaches the infective stage (cystacanth). When small mammals ingest the infected insects, the larval stage is encapsulated in the body cavity or muscles.

An additional fact that makes the presence of acanthocephalan larval stages in $S$. etruscus difficult is the nature of the insect intermediate host. The $S$. etruscus diet consists mainly of arthropods, with the exception of certain species: those chemically protected (like Graphosoma), too strongly chitinized like various Tenebrionidae beetles (Blaps, Scaurus, etc.); and those exceeding a certain size (like large Orthoptera) [18]. Laboratory studies on acanthocephalan life cycles typically used Tenebrio molitor as intermediate host since it is well-known that acanthocephalans with terrestrial life cycles usually infect well chitinized insects, especially Coleoptera and Orthoptera, thus making its presence, particularly in $S$. etruscus, difficult.

We would like to highlight the very low prevalence of adult nematode species, only $1.20 \%$ (Table 1), among the individuals of S. etruscus analyzed. However, 50 out of the $69(72.46 \%)$ C. russula studied in the same Banyuls/Cerbère area harbored adult nematodes (unpublished data). Several species of nematodes were found in the esophagus, stomach, intestine, respiratory system, bladder, spleen, and liver of the greater white-toothed shrew. The reasons why, apparently, nematodes have not been able to colonize and/or adapt to $S$. etruscus pose a complex issue, considering that Nematoda is the most speciose phylum after Arthropoda, with about 12,000 species in vertebrates only [70]. At microevolutionary scale, host ecology and physiology have a strong influence on the evolution of host-parasite interactions, with both factors acting as 'filters' [71]. Like all mammals, S. etruscus is considered homeothermic; however, Etruscan shrews can enter a state of torpor to save energy when experiencing cold stress or food restriction [72]. Body temperature can fall as low as $6^{\circ} \mathrm{C}$. According to our results, the particular physiology of the smallest living mammal could have a negative influence, particularly, on its nematode fauna.

Considering data on the parasite species richness of other shrews of the Suncus genus, there are only information on S. murinus and S. varilla minor. The helminth community of the Asian house shrew, S. murinus, a commensal species that can weigh up to $150 \mathrm{~g}$ and measure $10-15 \mathrm{~cm}$, is well-known and comprises more than 60 parasite species, specifically, four trematodes, almost 40 cestodes, and about 20 nematode species [57], as a result of hundreds of individuals analyzed. However, 39 individuals of this shrew analyzed in Cambodia harbored only five species [57], which clearly reinforces the positive correlation between sample size and parasite richness. Only two individuals of the African lesser dwarf shrew, S. varilla minor, have been parasitologically analyzed so far. Only one (new) tapeworm species has been reported in one of the two shrews studied, specifically the intestinal hymenolepidid Rodentolepis gnoskei Greiman and Tkach, 2012 [73], apparently specific of this shrew.

No specimens of $S$. etruscus have been studied in the same locations in which the Etruscan shrew coexists with $S$. murinus or $S$. varilla minor, to ascertain the specificity of $S$. etruscus helminth community. However, no adult helminth species detected in S. etruscus has ever been reported neither in any other shrew nor in any other small mammal, which suggests, regardless of their richness, the specificity of the S. etruscus helminth community, in particular of its cestode fauna. This result is consistent with the current knowledge on the specificity of cestodes parasitizing insectivorous mammals and this is particularly characteristic of shrew cestodes of the family Hymenolepididae, which are preferably mesostenoxenous (parasites which have more than one host species but restricted to one genus [74]). However, in the case of S. etruscus, its cestodes seem to have a higher degree of specificity, i.e., they are oioxenous (parasites that have only one host species [74]).

\subsection{Helminth Diversity and S. etruscus Body}

Mammalian orders vary greatly in the number of parasite species they harbor which is true for both endo- and ectoparasites. As the host body is the habitat for endoparasites, variation in body characteristics such as body size, metabolic rate, and longevity have often been considered determinant factors of parasite diversity [75]. S. etruscus has the 
smallest body size among mammals, a high oxygen consumption (while resting 67 times as much as resting humans) [28], and a short life span (16-18 months). The impact these intrinsic factors may have on the helminth diversity of the smallest living mammal deserves evaluation. However, we are aware of the fact that most of the S. etruscus analyzed in this study come from a single geographical area (Banyuls/Cerbère), while S. etruscus has a wide geographical distribution around the world, as pointed out in the Introduction section. This fact considerably limits the interpretation of the results obtained herein since other essential elements, also determinants of the helminth richness such as extrinsic factors (quality and diversity of habitat, season, etc.), as well as the analysis of the results according to the host population densities (host population density is one of the most important factors influencing the spread and distribution of parasites among host individuals [76]), could not be considered in this study.

It has been suggested that small-bodied mammals present a higher parasite diversity than large-bodied mammals. However, whilst some studies reported a positive correlation between parasite species richness and body size in mammals, other studies did not find this correlation [75]. According to our results, only seven parasite species were detected, and most of the individuals of S. etruscus analyzed (64.29\%) harbored only one parasite species. However, the lack of helminthological results in other very small mammals such as the Bumblebee bat (Craseonycteris thonglongyai) or the Pygmy jerboa (Salpingotulus michaelis) do not allow to ascertain the real extent of the influence of the body size on the richness of the helminth communities.

Concerning the metabolic rate, its influence on parasite richness is also controversial [75]. It was hypothesized that high host metabolic rates could increase the probability of acquisition of parasites through increased food intake [77]. S. etruscus has a high basal metabolic rate reflective of their high surface area-to-volume ratio. They cannot survive for more than a few hours without food, and they must consume as much as six times their body weight in crickets and other insects on a daily basis [78]. This high food intake could increase the probability of parasite acquisition through the ingestion of the arthropod intermediate hosts. However, according to our results, this high metabolic rate and food intake of $S$. etruscus do not seem to exert a significant influence on the acquisition of parasites.

In general, the relationship between host species longevity and parasite diversity is poorly known. It was pointed out that parasite species richness was negatively correlated with host longevity independent of body mass [79]. In general, regardless of the species, shrews usually live between one to two years. Therefore, no conclusion can be reached on the influence of longevity in parasite diversity since S. etruscus has a similar lifespan as other shrew species which exhibit considerable higher parasite richness [17].

\section{Conclusions}

No data on the helminth community of the smallest living mammal in the world had been available until the 1980s when the descriptions of the three new species of intestinal cestodes were published [31-33]. Herein, the only study considering the global helminth spectrum of $S$. etruscus has been presented.

Although further molecular studies are required to ascertain the taxonomic status of the tapeworm of the genus Pseudhymenolepis found, current evidence seems to indicate that it is specific of $S$. etruscus, like the remainder of its adult cestode fauna.

Concerning the finding of two individuals of the genus Anchotheca in the stomach of the Etruscan shrew, obtaining new material is essential to carry out the specific identification. However, taking into account both the problematic trapping of S. etruscus as well as the considerably low prevalence of the nematode herein reported (1.33\%, Table 2$)$, it seems that the specific identification of the nematode is going to remain an open question in the foreseeable future.

According to our results, with the exception of the extraintestinal metacestodes reported, the helminth community of S. etruscus seems to be highly specific, i.e., oioxenous, and closely related to its insectivore diet. 
Due to its small size, S. etruscus has undergone numerous physiological adaptations that have probably influenced its helminth spectrum, that is, the cestode specificity, the lack of trematodes and acanthocephalans, as well as the poorness of its nematode fauna. At any rate, and as it happens with any other correlation involving a host trait and parasite diversity, more than one process is probably involved, and all of these processes have contributed to shaping the observed helminth community pattern. Consequently, not only intrinsic factors of S. etruscus, but also the already mentioned extrinsic ones (host population densities, quality and diversity of habitat, season, environmental conditions, etc.) should be analyzed. Herein, the insufficient host sample size prevented a statistical study, making this type of analysis impossible.

In order to definitely characterize the S. etruscus helminth community, a larger host sample size should be obtained from different zones of its geographical distribution. However, the difficulty of trapping this minuscule mammal—several times highlightedmakes obtaining a significative number of individuals from different localities, rather unlikely. Therefore, notwithstanding the limitations we have faced in terms of material availability, we consider these first data on the helminth community of the smallest living mammal on Earth remarkable.

Author Contributions: Conceptualization, M.T.G.-P. and S.M.-C.; methodology, M.T.G.-P., S.M.-C., M.A.V. and M.V.F.; statistical analysis, M.V.F.; formal analysis, M.T.G.-P., S.M.-C.; M.A.V. and M.V.F.; writing—original draft preparation, M.T.G.-P.; writing—review and editing, M.T.G.-P., S.M.-C., M.A.V. and M.V.F. All authors have read and agreed to the published version of the manuscript.

Funding: This research received no external funding.

Institutional Review Board Statement: No ethical approval was required at the time Dr Fons conducted his surveys, i.e., in the nineteen sixties-eighties.

Data Availability Statement: Not applicable.

Acknowledgments: We would like to thank Jean Pierre Clara (1939-1998) and Thierry Fons for their invaluable collaboration in trapping the shrews. Likewise, we thank Angela Debenedetti for her illustrative drawings.

Conflicts of Interest: The authors declare no conflict of interest.

\section{References}

1. Nowak, R.N. Suncus: Musk Shrews, or Pygmy Shrews. In Walker's Mammals of the World, 6th ed.; Novak, R.M., Ed.; Johns Hopkins University Press: Baltimore, MD, USA, 1999; pp. 223-225.

2. Libois, R.; Fons, R. Suncus etruscus (Savi, 1822), the pygmy white-toothed shrew. In The Atlas of European Mammals; Mitchell-Jones, A.J., Amori, G., Bogdanowicz, W., Krystufek, B., Reijnders, P.J.H., Spitzenberger, F., Stubbe, M., Thissen, J.B.M., Vohralik, V., Zima, J., Eds.; Poyser Natural History: London, UK, 1999; pp. 76-77.

3. Alekseev, S.K.; Sheftel, B.I. The pygmy white-toothed shrew, (Suncus etruscus (Savi, 1822)): A species new to the fauna of Russia. Biol. Bull. 2018, 96, 1078-1084. [CrossRef]

4. Fons, R. Méthodes de capture et d'élevage de la Pachyure étrusque, Suncus etruscus (Savi, 1822). Z. Säugetierkd. 1974, 39, $204-210$.

5. Fons, R. Contribution à la connaissance de la Pachyure étrusque Suncus etruscus (Savi, 1822). Bull. Soc. Ecol. 1976, 7, 238-244.

6. Fons, R. Contribution à la connaissance de la Musaraigne étrusque Suncus etruscus (Savi, 1822) Mammifère, Soricidae. Vie Milieu 1970, 21, 209-218.

7. Fons, R.; Saint Girons, M.C. Notes sur les Mammifères de France. XIV. Donées morphologiques concernant la Pachyure étrusque, Suncus etruscus (Savi, 1822). Mammalia 1975, 39, 685-688. [CrossRef]

8. Sans Coma, V.; Fons, R.; Vesmanis, I.E. Eine morphometrische untersuchung and Schädel der Etruskerspitzmaus Suncus etruscus (Savi, 1822) aus Süd-Frankreich (Mammalia, Insectivora). Abh. Staatl. Mus. TierkdeDresden 1981, 37, 1-31.

9. Vesmanis, I.E.; Sans-Coma, V.; Fons, R. Bermerkungen über die Moephologische Variation des P4 bei verschiedenen rezenten Crocidura_Arten und Suncus etruscus im Mittelmeergebiet. Afr. Small Mamm. Newsl. 1979, 3, 16-18.

10. Vesmanis, I.E.; Fons, R.; Sans-Coma, V. Die Etruskerspitzmaus Suncus etruscus (Savi, 1822) in Tunesien (Mammalia, Insectivora). Afr. Small Mamm. Newsl. 1980, 3, 1-46.

11. Hartge, R.; Fons, R.; Schneider, J. Uber die Feinstruktur der Plazenta des Kleinsten Säugetirs der Welt der Etruskerspitzmaus Suncus etruscus Was unterscheidet sie von jener des Gröften Säugers des Blauwals (Balena, Cetacea)? Physiol. Pathol. Fortpfl. Verhandl. 1982, 7, 37-43. 
12. Fons, R.; Mas-Coma, S.; Galán-Puchades, M.T.; Valero, M.A.; Moutou, F. Parasitological suggestions on the evolution and systematics of Suncus and other genera of Soricidae (Mammalia: Insectivora). Zool. Jahr. Abt. Systematik. 1994, 121, 335-344.

13. Fons, R. Modalités de la reproduction et development post-natal en captivité chez Suncus etruscus (Savi, 1822). Mammalia 1973, 37, 288-324. [CrossRef]

14. Fons, R. Rythmes circadiens d'activité d'une petite musaraigne Suncus etruscus (Mammalia—Insectivora). Bull. Gr. Etud. Rhythm. Biol. 1973, 5, 1-9.

15. Fons, R. La mue chez les Crocidurinae: I-Changement de pelage dans la nature et captivité chez la Pachyure étrusque S. etruscus. Mammalia 1974, 38, 265-284.

16. Fons, R. Premières données sur l'écologie de la Pachyure étrusque Suncus etruscus (Savi, 1822)—Comparison avex deux autres Crocidurinés, Crocidura russula (Hermann, 1780) et Crocidura suaveolens (Pallas, 1881) (Insectivora, Soricidae). Vie Milieu 1975, 25, 315-359.

17. Fons, R. Durée de vie chez la Pachyure étrusque, Suncus etruscus (Savi, 1822) dans la nature et en captivité (Insectivora, Soricidae). Z. Säugetierkd. 1978, 44, 241-248.

18. Fons, R. Le répertoire comportemental de la Pachyure étrusque, Suncus etruscus (Savi, 1822). Rev. Ecol. (Terre Vie) 1974, 28, 131-157.

19. Fons, R.; Saint-Girons, R. Horaire et intensité de l'activité locomotrice spontanée chez un petit mammifère, la Pachyure étrusque, Suncus etruscus (Insectivora, Soricidae). Bull. Gr. Etud. Rhythm. Biol. 1976, 8, 95-106.

20. Saint Girons, M.C.; Fons, R. Activité locomotrice spontanée chez un mâle senile de Pachyure étrusque, S. etruscus (Savi, 1822). Mammalia 1978, 42, 257-260.

21. Fons, R.; Sicart, R. Contribution à la connaissance du métabolisme énergétique chez deux Crocidurinés: Suncus etruscus et Crocidura russula (Mammifère, Insectivora). Mammalia 1976, 40, 299-311. [CrossRef]

22. Fons, R.; Sablé, R.; Sicart, R. Quelques aspects des métabolismes glucidique et lipidique chez deux Insectivores Crocidurinae, Suncus etruscus (Savi, 1822) et Crocidura russula (Hermann, 1780) (Mammifère-Soricidae). Vie Milieu 1977, 21, 129-144.

23. Sicart, R.; Sablé, R.; Fons, R. Comparative aspect of lipid metabolism in two shrews (Suncus etruscus and Crocidura russula). Comp. Biochem. Physiol. 1978, 61, 77-80. [CrossRef]

24. Bartels, H.R.; Baumann, R.; Fons, R.; Jürgens, K.D.; Wright, P. La fonction respiratoire du sang et poids relatif de certains organes chez deux espèces de Musaraigne: Crocidura russula et Suncus etruscus (Mammifère, Soricidae). C. R. Acad. Sci. Paris 1978, 286, 1195-1198.

25. Bartels, H.R.; Baumann, R.; Fons, R.; Jürgens, K.D.; Wright, P. Blood oxygen transport function in Etruscan shrews. Pflügers Archiv. 1978, 373, 44 .

26. Bartels, H.R.; Baumann, R.; Fons, R.; Jürgens, K.D.; Wright, P. Blood oxygen transport and oxygens weights of two shrews, Suncus etruscus and Crocidura russula. Am. J. Physiol. 1979, 236, 221-224.

27. Jürgens, K.D.; Peter, T.; Sender, S.; Fons, R.; Gros, G. Carbonic anhydrase activities of blood, lung and heart of the smallest mammal, the Etruscan shrew (Suncus etruscus). Pflügers Arch. Eur. J. Physiol. 1994, 426, 135.

28. Jürgens, K.D.; Fons, R.; Peter, T.; Sender, S. Heart and respiratory rates and their significance for convective oxygen transport rates in the smallest mammal, the Etruscan shrew Suncus etruscus. J. Exp. Biol. 1996, 199, 2579-2584. [CrossRef]

29. Fons, R.; Sender, S.; Peters, T.; Jürgens, K.D. Rates of rewarming, heart and respiratory rates and their significance for oxygen transport during arousal from torpor in the smallest mammal, the Etruscan shrew Suncus etruscus. J. Exp. Biol. 1997, 200, 1451-1458. [CrossRef]

30. Peters, T.; Kubis, H.P.; Wetzel, P.; Sender, S.; Asmussen, G.; Fons, R.; Jurgens, K.D. Contraction parameters, myosin composition and metabolic enzymes of skeletal muscles of the Etruscan shrew Suncus etruscus and of the Common European white-toothed shrew Crocidura russula. J. Exp. Biol. 1999, 202, 2461-2473. [CrossRef]

31. Mas-Coma, S.; Fons, R.; Galán-Puchades, M.T.; Valero, M.A. Hymenolepis claudevaucheri n. sp. (Cestoda: Hymenolepididae), first record of a helminth in the smallest known living mammal, Suncus etruscus (Savi, 1822) (Insectivora: Soricidae). Critical revision of the Cyclophyllidea in Suncus murinus (Linnaeus, 1766). Vie Milieu 1984, 34, 117-126.

32. Mas-Coma, S.; Fons, R.; Galán-Puchades, M.T.; Valero, M.A. Description de Hymenolepis cerberensis n. sp. (Cestoda: Hymenolepididae) et premières considérations générales sur la faune de Cestodes parasites de la Pachyure étrusque, Suncus etruscus (Savi, 1822) (Insectivora: Soricidae). Ann. Parasitol. Hum. Comp. 1986, 4, 411-422. [CrossRef]

33. Mas-Coma, S.; Fons, R.; Galán-Puchades, M.T.; Valero, M.A. Hymenolepis banyulsensis n. sp. (Hymenolepididae), un nouveau Cestode parasite de la Musaraigne étrusque (Soricidae) dans la région de Banyuls-sur-Mer (France). Rev. Suisse Zool. 1986, 93, 329-339. [CrossRef]

34. Bush, A.O.; Lafferty, K.D.; Lotz, J.M.; Shostak, A.W. Parasitology meets ecology its own terms: Margolis et al. revisited. J. Parasitol. 1997, 83, 575-583. [CrossRef]

35. Georgiev, B.B.; Bray, R.A.; Littlewood, D.T.J. Cestodes of small mammals: Taxonomy and life cycles. In Micromammals and Macroparasites. From Evolutionary Ecology to Management; Morand, S., Krasnov, B.R., Poulin, R., Eds.; Springer: Tokyo, Japan, 2006; pp. $29-62$.

36. Conn, B.C.; Galán-Puchades, M.T.; Fuentes, M.V. Normal and aberrant Mesocestoides tetrathyridia from Crocidura spp. (Soricimorpha) in Corsica and Spain. J. Parasitol. 2011, 97, 915-919. [CrossRef] [PubMed] 
37. Loos-Frank, B. One or two intermediate hosts in the life cycle of Mesocestoides (Cyclophyllidea, Mesocestoididae)? Parasitol. Res. 1991, 77, 726-728. [CrossRef]

38. Sapp, S.G.H.; Bradbury, R.S. The forgotten exotic tapeworms: A review of uncommon zoonotic Cyclophyllidea. Parasitology 2020, 147, 533-558. [CrossRef] [PubMed]

39. McAllister, C.T.; Tkach, V.V.; Bruce, D.B. Morphological and molecular characterization of post-larval pre-tetrathyridia of Mesocestoides sp. (Cestoda: Cyclophyllidea) from Ground Skink, Scincella lateralis (Sauria: Scincidae), from southeastern Oklahoma. J. Parasitol. 2018, 104, 246-253. [CrossRef] [PubMed]

40. Galán-Puchades, M.T. Contribución al Conocimiento de la Fauna de Plathelmintos Parásitos de Crocidurinae (Insectivora: Soricidae) en el Marco Europeo Continental e Insular del Mediterráneo Occidental. Ph.D. Thesis, University of Valencia, Valencia, Spain, 1986.

41. Conn, D.B. The rarity of asexual reproduction among Mesocestoides tetrathyridia (Cestoda). J. Parasitol. 1990, 76, 453-455. [CrossRef]

42. Galán-Puchades, M.T.; Fuentes, M.V.; Conn, D.B. A new type of endogenous asexual proliferation in cyclophyllidean metacestodes. Acta Parasitol. 2002, 47, 288-293.

43. Schuster, R.K. Cestodes of the genera Diplopylidium and Joyeuxiella (Eucestoda: Dipylidiiae)—A review of historical data, species inventory and geographical distribution. Sci. Parasitol. 2020, 21, 1-17.

44. Mas-Coma, S.; Esteban, J.G.; Fuentes, M.V.; Bargues, M.D.; Valero, M.A.; Galán-Puchades, M.T. Helminth parasites of small mammals (Insectivores and Rodents) on the Pityusic Island of Eivissa (Balearic Archipelago). Res. Rev. Parasitol. 2000, 60, 41-49.

45. Schuster, R.; Montag, A. Joyeuxiella pasqualei-An unusual tapeworm in an indigenous domestic cat. Kleintierpraxis 2000, 11, 867-870.

46. Joyeux, C. Recherches sur la fauna helminthologique Africaine. 2. Cestodes. Arch. Inst. Pasteur Tunis 1923, 14, $119-167$.

47. Czaplinski, B.; Vaucher, C. Family Hymenolepididae. In Keys to the Cestode Parasites of Vertebrates; Khalil, L.F., Bray, R.A., Eds.; CAB International: Oxon, UK, 1994; pp. 595-663.

48. Mas-Coma, S. Helminthes de micromammifères. Spécificité, évolution et phylogénie des Cestodes Arostrilepididae Mas-Coma et Tenora, 1981 (Cyclophyllidea: Hymenolepidoidea). Mém. Mus. Nat. Hist. Nat. Ser. A Zool. 1982, 123, $185-194$.

49. Vaucher, C. Les Cestodes parasites des Soricidés d'Europe. Etude anatomique, révision taxonomique et biologie. Rev. Suisse Zool. 1971, 78, 1-113. [CrossRef] [PubMed]

50. Hunkeler, P. Les Cestodes parasités des petits mammifères (Rongeurs et Insectivores) de Côte-d'Ivoire et de Haute-Volte. Rev. Suisse Zool. 1974, 80, 809-930. [CrossRef]

51. Vaucher, C. Cestodes parasites de Crocidura suaveolens (Pallas) en Grèce, avec description de Pseudhymenolepis graeca n. sp. et remarques sur Pseudhymenolepis solitaria (Meggit, 1927) n. comb. Bull. Soc. Neuchâtel. Sc. Nat. 1984, 107, 197-202.

52. Sawada, I.; Koyasu, K. Pseudhymenolepis nepalensis sp. nov. (Cestoda: Hymenolepididae) parasitic on the house shrew, Suncus murinus (Soricidae) from Nepal. Zool. Sci. 1991, 8, 575-578.

53. Sawada, I.; Harada, M. A new species of the genus Pseudhymenolepis (Cestoda, Hymenolepididae) from Insectivora of Central Japan with record of the known Cestoda species. Proc. Jpn. Soc. Syst. Zool. 1991, 44, 8-14.

54. Velikanov, V.P. New species of the genus Pseudhymenolepis (Cestoda: Hymenolepididae) from the white-toothed shrew. Parazitologia 1997, 31, 210-222. (In Russian)

55. Tkach, V.V.; Velikanov, V.P. Pseudhymenolepis turkestanica sp. N. (Cestoda: Hymenolepididae), a new cestode from shrews. Ann. Parasitol. Hum. Comp. 1991, 66, 54-56. [CrossRef]

56. Sawada, I.; Ohono, N. Some cestodes parasites of the Indian House Mausk Shrew, Suncus murinus. Jpn. J. Parasitol. 1993, 42, 381-387.

57. Veciana, M.; Chaisiri, K.; Morand, S.; Ribas, A. Helminths of the Asian House shrew Suncus murinus from Cambodia. Cambodian J. Nat. Hist. 2012, 2012, 115-122.

58. Gupta, S.P.; Sinha, N. On a new cestode Pseudhymenolepis suncusi sp. N. (Fam. Hymenolepididae Railliet et Henry, 1909) from a common shrew, Suncus striatus Lucknow. Ind. J. Helminth. 1984, 36, 89-92.

59. Gupta, V.; Singh, S.R. On a new species Pseudhymenolepis guptai sp. n. (Cyclophyllidea: Hymenolepididae) from Suncus striatus from Khurja, U.P. Ind. J. Helminth. 1987, 39, 92-95.

60. Tkach, V.V.; Zhumabekova, B.K. Helminth fauna of shrews in southeastern Kazakhstan. In Proceedings of the Paraztologiya v Ukraini: Vchora, Sogodni, Zavta. Mat Yuvil. Konf. UNTP 16-17, Travnya, Ukraine, 16-17 May 1995; pp. 101-110. (In Russian).

61. Quentin, J.-C.; Beaucournu, J.-C. Cysticercoides d'Hymenolepididae parasites d'insectivores chez les Siphonapteres. C. R. Acad. Sci. 1966, 262, 2059-2062.

62. Gabrion, C. Presence de cysticercoides d'un cestode cysclophillidae chez un arachnide, Phalangium opilio. Ann. Parasitol. Hum. Comp. 1977, 52, 229-234. [CrossRef] [PubMed]

63. Beaucournu, J.-C.; Lorvelec, O. Mise à jour taxonomique et répartition des puces du genre Ctenothalmus Kolenati 1856 en région paléarctique occidentale (Insecta: Siphonaptera: Ctenophthalmidae). Ann. Soc. Entomol. Fr. 2014, 50, 219-247. [CrossRef]

64. Moravec, F. Proposal of a new systematic arrangement of the nematodes of the family Capillariidae. Folia Parasitol. 1982, 29, 119-132.

65. Mas-Coma, S.; Galán-Puchades, M.T. Consideraciones sobre el género Aonchotheca López-Neyra, 1947 (Nematoda: Trichuridae). Circ. Farm. 1985, 286, 3-20. 
66. Asakawa, M.; Kamiya, H.; Ohbayashu, M. Studies on the parasite fauna of Insectivora. II. Four new capillarid nematodes from the Japanese shrews, genera Suncus and Crocidura. J. Coll. Dairy. Nat. Sci. Jpn. 1988, 12, 335-347.

67. Umur, S.; Moravec, F.; Gurler, A.; Bolukbas, C.; Acici, M. First report on Aonchotheca annulosa Dujardin, 1845 (Nematoda, Capillariidae) in a Hamadrya baboon (Papio hamadryas) from a zoo in northern Turkey. J. Med. Primatol. 2012, 41, $384-387$. [CrossRef]

68. Anderson, L.C. (Ed.) Nematode Parasites of Vertebrates. Their Development and Transmission; CABI Publishing: Wallingford, UK, 2000; 650p.

69. Ribas, A.; Casanova, J.C. Acanthocephalans. In Micromammals and Macroparasites. From Evolutionary Ecology to Management; Morand, S., Krasnov, B.R., Poulin, R., Eds.; Springer: Tokyo, Japan, 2006; pp. 81-89.

70. Morand, S.; Bouamer, S.; Hugot, J.P. Nematodes. In Micromammals and Macroparasites. From Evolutionary Ecology to Management; Morand, S., Krasnov, B.R., Poulin, R., Eds.; Springer: Tokyo, Japan, 2006; pp. 63-79.

71. Koprivnikar, J.; Randhawa, H.S. Benefits of fidelity: Does host specialization impact nematode parasite life history and fecundity. Parasitology 2016, 140, 587-597. [CrossRef] [PubMed]

72. Berg, M. A minuscule model for research. Nature 2016, 45, 133. [CrossRef]

73. Greiman, S.E.; Tkach, V.V. Description and phylogenetic relationship of Rodentolepis gnoskei n. sp. (Cyclophyllidea: Hymenolepididae) from a shrew Suncus varilla minor in Malawi. Parasitol. Int. 2012, 61, 343-350. [CrossRef]

74. Pojmanska, T.; Niewiadomska, K. New trends in research on parasite host specificity: A survey of current parasitological literature. Ann. Parasitol. 2012, 58, 57-61. [PubMed]

75. Krasnov, B.R.; Poulin, R.; Morand, S. Patterns of macroparasites diversity in small mammals. In Micromammals and Macroparasites. From Evolutionary Ecology to Management; Morand, S., Krasnov, B.R., Poulin, R., Eds.; Springer: Tokyo, Japan, 2006 ; pp. $197-231$.

76. Anderson, R.M.; May, R.M. Regulation and stability of host-parasite population interactions. I. Regulatory processes. J. Anim. Ecol. 1978, 7, 219-247. [CrossRef]

77. Bell, G.; Burt, A. The comparative biology of parasite species diversity: Intestinal helminths of freshwater fishes. J. Anim. Ecol. 1991, 60, 1046-1063. [CrossRef]

78. Brecht, M.; Naumann, R.; Anjum, F.; Wolfe, J.; Munz, M.; Mende, C.; Roth-Aleperman, C. The neurobiology of Etruscan shrew active touch. Phil. Trans. R. Soc. B 2011, 366, 3026-3036. [CrossRef]

79. Morand, S.; Harvey, P.H. Mammalian metabolism, longevity and parasite species richness. Proc. R. Soc. Lond. B 2000, 267, 1999-2003. [CrossRef] 